\title{
Profitability of Small-Scale Integrated Fish-Rice-Poultry Farms in Cameroon
}

\author{
Benedicta Oshuware Oben ${ }^{1}$, Ernest L. Molua ${ }^{2,3}$ \& Pius M. Oben ${ }^{1}$ \\ ${ }^{1}$ Department of Animal Science, Fishery and Applied Animal Science Programme, University of Buea, \\ Cameroon \\ ${ }^{2}$ Department of Agricultural Economics \& Agribusiness, University of Buea, Cameroon \\ ${ }^{3}$ Centre for Independent Development Research, Buea, Cameroon \\ Correspondence: Ernest L. Molua, Department of Agricultural Economics \& Agribusiness, University of Buea, \\ P.O. Box 63 Buea, Southwest Region, Cameroon. Tel: 237-699-494-393. E-mail: emolua@cidrcam.org
}

Received: July 28, 2015 Accepted: September 10, 2015 Online Published: October 15, 2015

doi:10.5539/jas.v7n11p232 URL: http://dx.doi.org/10.5539/jas.v7n11p232

\begin{abstract}
There are increasing efforts from diverse national and international stakeholders promoting integrated aquaculture for its merit in meeting the triple needs of food production, social relevance and environmental stability. This research studies 120 aquaculture producers in the Southwest and Northwest regions of Cameroon. The hypothesis is that socioeconomic parameters influence farmers' selection of an enterprise mix amongst fish-rice-poultry that will maximize revenue. A revenue equation is estimated by imposing a Cobb-Douglas functional form. About $35 \%$ of farmers practiced integrated systems, and for those that did not practice in situ integrated systems, about $65 \%$ undertook these different enterprises at different times within the same calendar year. The combination of poultry with fish-rice enterprises is practised as a means to increase farm income through better resource utilization. The systems are overall profitable. When integration is undertaken for two systems either as fish cum rice, fish cum poultry or rice cum poultry farmers realize annual net returns of 428,630 FCFA (US\$ 857); 785,650 FCFA (US\$ 1,571) and 865,990 FCFA (US\$ 1,732), respectively. The highest profits of 965,270 FCFA (US\$ 1,931) are obtained in the complete fish-rice-poultry system. Econometric estimates of the revenue function reveal positive and direct relationship with farm revenue for socioeconomic parameters such as plot size, labour, credit, education, land tenure, access to extension and enterprise integration. For dissemination and adoption of this technology there is need for training that exploit pond management and marketing of products from the system.
\end{abstract}

Keywords: integrated aquaculture, rice, fish, poultry, profitability, Cameroon

\section{Introduction}

Open-access capture fishery is increasingly being supplemented with fish farming. Integrated aquaculture is gaining prominence and adopted to maximize economic and environmental potentials (Ayoola, 2010; FAO, 2000; Vincke, 1992). Cameroon's evolving socio-economic and environmental conditions are promoting integrated aquaculture, particularly for small-scale farmers growing fish as an integral part of their agricultural systems. Agriculture-Aquaculture integration is a complementary interaction between crops, livestock and fish as a farming system that focuses diversified agricultural production with emphasis on fish (FAO, 2004; Edwards, 1998). There is variation in the occurrence and importance of aquaculture throughout Africa and Cameroon, with many local differences in the levels of integration employed (Kipkemboi et al., 2006; Fakoya \& Daramola, 2005; Ofori et al., 2005; Pouomogne \& Brummett, 2002). While most farmers are in crop-based systems, few culture fish and of those that do, most produce less than their resource base would allow. However, its potential for poverty alleviation and food security is yet to be fully exploited in concrete terms (Edwards \& Little, 2003; Lewis, 1997; Williams, 1997).

For Cameroon inadequacy of protein levels could be related to the levels of fish and poultry intake. Figure 1 depicts this inadequacy. In 1961 freshwater fish consumption was $5 \mathrm{~kg}$ per capita per year which declined drastically to the late 1960 s, and its eventual recovery which peaked in 2005 was still below the 1960 levels. Poultry meat consumption has steadily increased since the 1960s but has overall remained below the fresh fish 
consumption levels. In 2004, consumption of poultry meat peaked at $4.8 \mathrm{~kg}$ per person per year. However, this is still below the required levels to guarantee significant levels of protein intake. This challenges offer opportunity for aquaculture to supplement the country's protein intake. Integrated aquaculture diversifies commodities to contribute to food security and improved incomes.

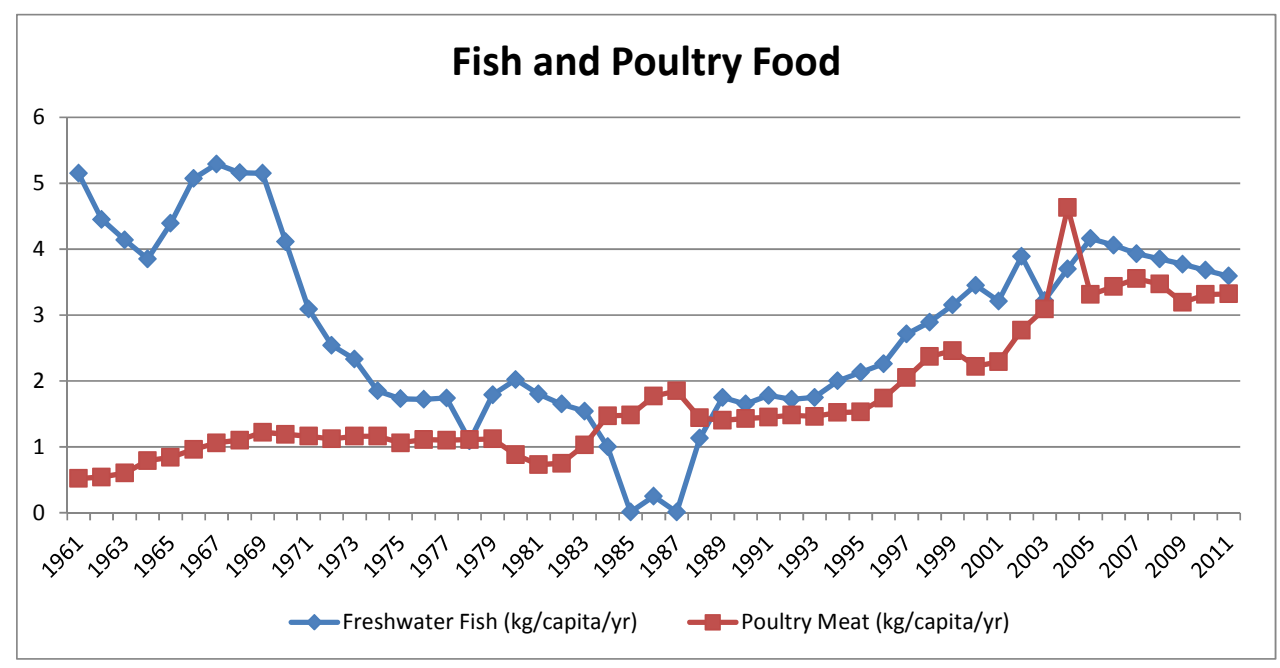

Figure 1. Basic food supply in Cameroon

Source: Authors' computation from FAOSTAT (2014).

The interaction of agriculture (crop and/or livestock) and aquaculture has spawned an Integrated Agriculture Aquaculture System (IAAS) (Edwards \& Little, 2003; FAO, 2000; Ingram et al., 2000). Some International Non-Governmental Organisations such as the FAO recommend IAAS for its merits of meeting triple needs of production, social relevance and environmental stability (FAO, 2000, 2014; Vincke, 1992). In Cameroon, aquaculture is promoted in areas where water supplies may ensure year-round production. Nonetheless, it has also been attractive where availability of water is seasonal. The integration of fish in rice fields by some farmers is attracting the attention of other non-practitioners, particularly in areas where flooded rice production is dominant (FAO, 2004). As shown in Figure 2 below the IAAS emphasizes three interrelated aspects of production, socio-economic and the environment.

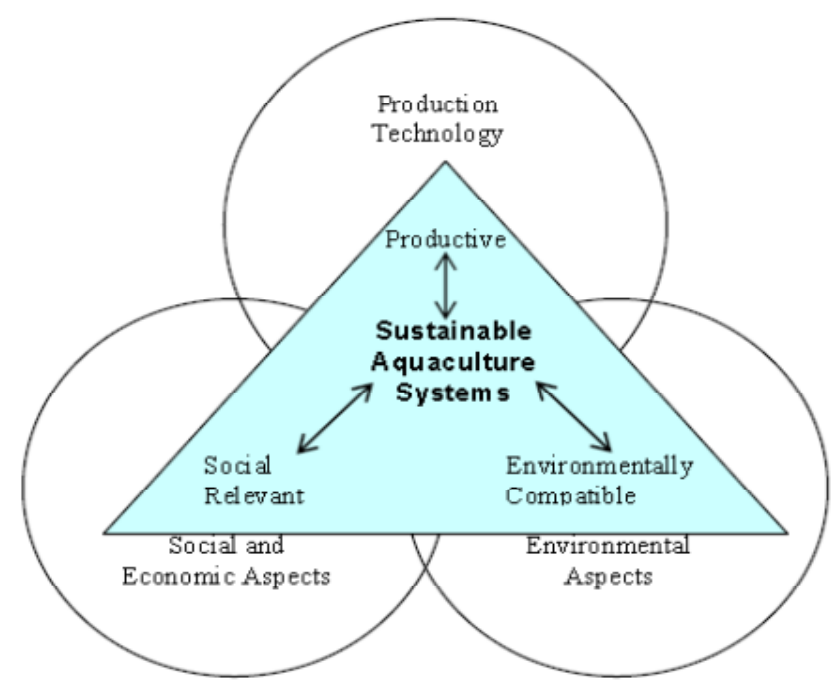

Figure 2. A system approach including production technology, social and economic aspects, and the environment, to promote sustainable aquaculture systems

Source: Edwards (1998). 
As indentified in the figure, the socioeconomic and environmental relevance of the system is driven by different needs including a desire to improve food security on small, subsistence family farms; or to minimise pollution and use valuable resources such as water more efficiently and effectively (Gabriel et al., 2007; Edwards, 1998). The overarching philosophy is to promote efficient utilization of farm space for multiple productions in such a way that limited land can be used for different purposes by which waste from one unit can be used to serve as input for other units (Kipkemboi et al., 2006; Ofori et al., 2005). Within the IAAS, production technology includes the species considered for culture, the culture facilities and husbandry employed for the various stages of production (hatchery for fry production, nursery to produce fingerlings for stocking, and grow-out for the final product, usually for human consumption). In East Africa, IAAS husbandry practices involve various methods of stock management (monoculture or polyculture; single or multiple stocking and harvesting strategies), use of different feeds (natural, supplementary or complete feed), management of substrate and water quality, and disease prevention and therapy (Kipkemboi et al., 2006). According to Eyo et al. (2006) and Ofori et al. (2005), in West Africa, IAAS is typically a complementary interaction between crops, livestock and fish in such a way that limited land can be used for different purposes. In Nigeria, Abiona et al. (2012) further notes that agriculture-aquaculture promotes efficient utilization of farm space for multiple productions.

Typical to sub-Saharan farmers, Cameroon's farmers have relied on land and water resources for agriculture and fishery, and their integration into a joint production system is significantly undermined by inadequate access to land and basic resources. The social and economic factors identified in Figure 2 above are examined by Wetengere (2009) to influence IAAS on two levels: the macro-level (international, national and regional or provincial) and micro-level (rural farming community, farm and farm household). According to Edwards (1998) the macro-level issues emanating from IAAS include world trade, national development policy and goals, social aspects such as cultural attitudes to recycling, and input supply and marketing. Micro-level issues mainly concern the alternative use of resources e.g. whether IAAS are an appropriate use of resources and whether they can be linked synergistically with other farm and non-farm activities (ibid). Folke and Kautsky (1992) identify the environment to cover natural resources such as land, water, biological diversity and nutrients. There is a two-way interaction between the external environment and the aquaculture system and influences are either positive or negative. A positive feature of IAAS is that they have the potential to exert a positive effect on the environment by utilising effluents or by-products from other adjacent or distant human activities (Gabriel et al., 2007; Krom et al., 2001). These and other potential benefits of IAAS prompted the CORAF/WECARD (Conseil Ouest et Centre Africain pour la Recherche et le Développement Agricoles/West and Central African Council for Agricultural Research and Development) World Bank/ Multi-Donor Trust Fund (MDTF) to fund a project for the actualization of sustainable integrated aquaculture development using fish, rice and poultry in three African countries- Cameroon, Nigeria and Sierra Leone. The Cameroon component of the project took off in October 2012 and forms the basis of this study.

\section{Method}

Purposive sampling techniques were used to select two aquaculture dominant divisions for each of the two regions of the Northwest and Southwest. Municipalities where aquaculture was prevalent were purposely selected to ensure predominance of integrated fish farmers in the data. In all, 120 farmers were then simply randomly sampled out of which 105 were available for interview within the municipalities of Muyuka, Yoke, Mamfe, Bafut, Ndop and Mbaw plain. Primary data was then collected from respondents using well-structured interview guides. This survey thus served as a baseline to guide the implementation of the innovation platform and extension outreach components for the CORAF/WECARD (Conseil Ouest et Centre Africain pour la Recherche et le Développement Agricoles/West and Central African Council for Agricultural Research and Development) World Bank/MDTF funded project for the actualization of sustainable integrated aquaculture development using fish, rice and poultry in the beneficiary countries. The complete data from 93 farmers was analysed using both descriptive and inferential statistics. Descriptive statistical tools were employed to describe the socio-economic characteristics of the aquaculture practitioners and their various enterprise combinations; meanwhile inferential statistics was used to test the null hypotheses. The hypothesis is that socioeconomic parameters such as product prices, farm size, labour, education, experience, gender, extension service contact and land tenure influence farmers' selection of an enterprise mix that will maximize revenue. We estimated a revenue equation by imposing a Cobb-Douglas functional form specified as:

$$
\ln R_{i}=\alpha_{0}+\alpha_{1} \ln Z_{1 i}+\beta_{k} \sum_{k=1}^{3} \ln P_{k i}+\delta \sum_{j=1}^{5} T_{j}+\varepsilon_{i}
$$

Where, $\mathrm{R}$ is total farm revenue for the $\mathrm{i}^{\text {th }}$ farmer, $\alpha$ and $\beta$ represent the individual variable coefficients in the dual of the stochastic frontier function; $\mathrm{Z}$ is the socioeconomic characteristics of the enterprises e.g. plot/land size, 
labour, capital, age of farmer, education, experience in practicing the technology; $\mathrm{P}_{\mathrm{ki}}$ are the prices per output in the farm enterprises e.g. fish, rice and/or poultry; $\delta$ is the regression coefficients for institutional characteristics measured as dummy e.g. gender, access to extension services and land tenure; $\varepsilon$ is an error term; and $i=1, \ldots n$ for the number of farms in the sample. The revenue per farm were measured as annual receipts from sales, farm size was the land exploited in hectares, labour was the man-day per year allocated for the production activities, age of farmer is chronological age in years, education was the number of years of schooling, experience is measured in years as the length of time the farmer has practiced integrated aquaculture technology, the output prices are the reported farm-gate prices experienced by each farmer for the sale of fish, rice and live poultry birds. The data for the other variables are captured as dummy, e.g. gender (male $=1$, female $=0$ ), access to extension service (contact $=1$, otherwise $=0$ ) and land tenure (formal land title $=1$, otherwise $=0$ ). A priori it is expected that increased farm size, higher levels of labour, older experienced farmers, education, increased access to credit opportunities and the ownership of land title (secure tenure) coupled with the availability of valuable extension service contacts will enhance farm output, and revenue and thus augment farm and household incomes.

\section{Results and Discussion}

\subsection{Socioeconomics of Integrated Fish Culture and Rice Cum Poultry Practitioners}

The average age of the predominantly male-head of the households (interviewee) is 56 years, with about $73 \%$ being married. About $45 \%$ of these had secondary education, $35 \%$ primary education and fewer proportions reporting university education. None reported not being scholarised. The sampled respondents were predominantly from Cameroon's Christian south regions with significant majority (91\%) reporting Christianity as their religious faith and the remaining $9 \%$ identifying either with African traditions or other belief system. The average family size is 8 , with household composition comprising of nuclear and extended family members, $65 \%$ of whom are below 18 years of age. About $68 \%$ report that their main source of income is from agriculture and $35 \%$ identified aquaculture as their major source of income. Few of the sampled farmers relied on gainful employment in civil service (5\%) and business $(17 \%)$ as their primary source of income, with aquaculture being for them alternative source of income. About $45 \%$ of sampled farmers belonged to farmers' association, that could be grouped as Economic Interest Groups (EIGs), Common Initiative Groups (CIGs), Cooperatives and Community Based Organisations (CBOs). These provided opportunities for about $24 \%$ of farmers to take part in integrated fish-farm training, of which $48 \%$ reported as being beneficial to their farming activities. Table 1 presents the summary statistics describing farmers' socio-economic status. The average revenue per farm is 1,272,000 Francs CFA (US\$ 2,544) (Note 1) for an average farm size of 1.580 hectares, pond size of 0.565 ha and rearing about 963 birds per year. For those engaged in other economic activities non-farm income averaged about 218,500 Francs CFA (US\$ 436) per year.

Table 1. Summary statistics of the descriptive variables

\begin{tabular}{lllll}
\hline Parameters & Minimum & Maximum & Mean & Standard Deviation \\
\hline Revenue per farm (FCFA) & 427000.00 & 2355000.00 & 1272000.00 & 695000.00 \\
Rice farm size (m.sq) & 320.00 & 2940.00 & 1580.00 & 940.00 \\
Fish pond size (m.sq) & 381.67 & 926.47 & 565.07 & 251.60 \\
Poultry herd size (birds) & 137.00 & 1565.00 & 963.00 & 572.00 \\
Rice price per kg & 250.00 & 483.50 & 298.75 & 127.65 \\
Fish price per kg & 385.00 & 620.00 & 431.50 & 136.50 \\
Poultry price per bird & 2300.00 & 4125.00 & 2921.50 & 722.50 \\
Age of farmer (years) & 31.00 & 62.00 & 56.50 & 16.50 \\
Education (years) & 0.00 & 17.00 & 7.75 & 7.50 \\
Experience (years) & 7.00 & 15.00 & 9.00 & 3.00 \\
Credit acquired (FCFA) & 98000.00 & 1345000.00 & 673500.00 & 532500.00 \\
Household size & 1.00 & 8.00 & 5.00 & 2.75 \\
Non-farm income & 0.00 & 379000.00 & 218500.00 & 175500.00 \\
\hline
\end{tabular}

Source: Survey 2013. 


\subsection{Production Technology and Associated Challenges}

Farms were studied on their potential to practice fish-rice-poultry as IAAS. The integrated system involving fish farming, poultry keeping and rice production, or diverse combination of any of these are practiced. The inter-relationships between the component parts of the system are illustrated in Figure 3. The system is based on the use of ponds which meet the needs of fish as well as enables rice to be grown in-situ or adjacent and compliments the rearing of poultry birds. The technical features of the integrated system are based on the complementarity of enterprises whereby nonmarketable crop residues, pond water and poultry manure for rice fields or maggots produced from manure are direct fish food. Demonstrable benefits in terms of significant income generation from the sale of fish, poultry and rice and some by-products like rice-bran are identified as perceived rationale for farmers' practice of the system. In the course of the year, enterprise products are sold within the farm or transported to nearby market-centres.

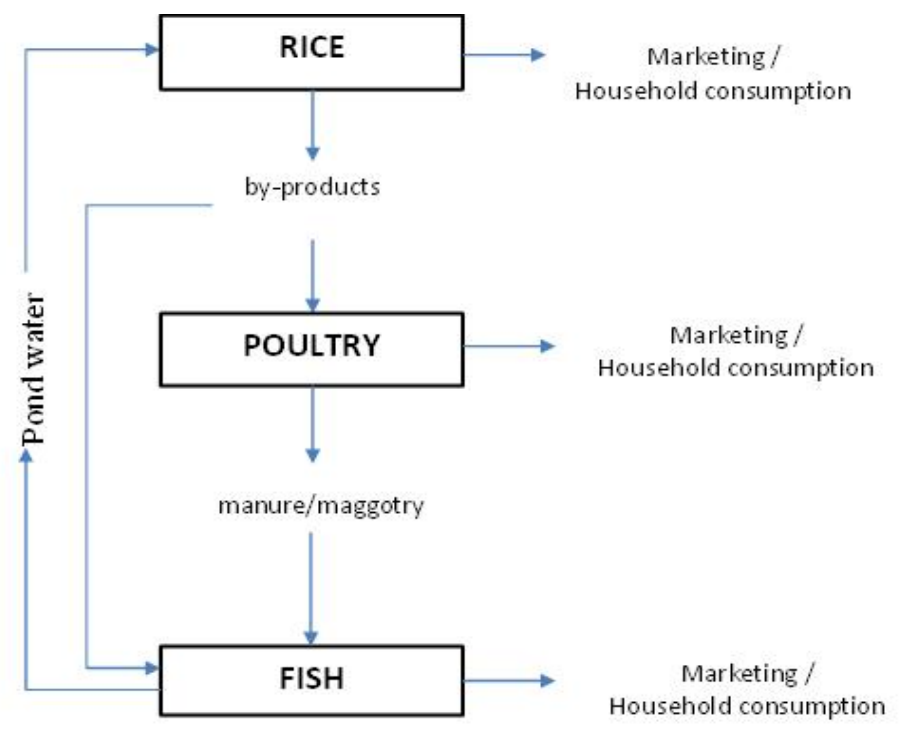

Figure 3. Interactions between the various enterprises in fish cum rice cum poultry integrated farm

However, the sustained practice of the system is largely dependent on the demand and market outlets, availability of supplementary feeds, availability of land for development and expansion, cost of pond construction and water supply, as well as the rising cost of feed and feed formulations. Given the production challenges, about $30 \%$ of farmers have over a certain period dropped one or more of these enterprises, and as such were no longer IAAS farmers. However, since they had potentials for IAAS, they were also studied to gain insights on the reasons for practicing or not of IAAS. For example, for about $65 \%$ of the farmers studied, poultry waste is gaining traction as input in rice crop farming. For such farmers, the complementarity of the system is ensured with the use of rice grain and bran as feed for poultry. The production system designs employed in the field range into one or more of the following three categories:

a. Intensive systems practiced by $17 \%$ of the farmers with typically high stocking density, and relatively high levels of capital investment, management and control (e.g. concrete tank-based systems). For these farmers who practiced intensive management systems, they owned on average 236 birds at any point in time in their poultry houses, with poultry houses averaging 225 sq. metres.

b. Semi-intensive systems practiced by $45 \%$ of the farmers employing medium stocking density and medium level capital investment, management and control (e.g. on-farm storage ponds and/or purpose built fish ponds).

c. Extensive system practiced by $38 \%$ of mostly part-time farmers with seasonal stocking of their ponds and minimal level of capital investment and control. This also includes exploitation of nearby wet/marshy lands, free range of poultry and intermittent cultivation of rice. For such production no supplementary feeding is provided to fish and poultry.

The typology for fish culture reveals that about $17 \%$ of farmers used tanks, $45 \%$ used ponds, $5 \%$ exploited rivers and streams, $23 \%$ used the lake facilities and $10 \%$ took advantage of swamp land. Some farmers used more than 
one of these mediums for aquaculture. The exploitation of sea water for fishing is reported by $5 \%$ of farmers studied. Those that relied on fish tanks or ponds, reported owning on average about 2.5 fish tanks/ponds. Water flow was noted as important, with most of the farmers relying on wet-season rainfall to intensify their fishing activity. However, in dryland areas with limited access to water, there is low attraction to the IAAS and decline in the production of fish. Most of these farmers are observed to operate on part-time basis. On operationalising the IAAS technology, about $35 \%$ of farmers practiced integrated systems. For those that did not practice in situ integrated systems, about $65 \%$ undertook these different enterprises at different times within the same calendar year. As noted in Table 2, this relate to $16 \%, 22 \%$ and $27 \%$ for fish, rice and poultry, respectively. Only about $12 \%$ cultivated rice at the same time that they grew fish, with another $6 \%$ undertaking fish and poultry as an integrated system. About $9 \%$ of farmers were involved in rice and fish integration, and another $8 \%$ of farmers are observed to cultivate rice at the same time that they rear birds and grow fish.

Table 2. Enterprise activities of fish-poultry related farming system

\begin{tabular}{ll}
\hline Farming systems & Proportion (\%) \\
\hline Solely fish & 16 \\
Solely rice & 22 \\
Solely poultry & 27 \\
Fish cum rice & 12 \\
Fish cum poultry & 6 \\
Rice cum poultry & 9 \\
Fish-rice-poultry & 8 \\
\hline
\end{tabular}

Note. Source: Survey 2013. $\mathrm{N}=93$. Percentages rounded to the nearest whole number.

Whether on different sites or in-situ, about $42 \%$ fed poultry and fish with by-products from rice farm. Another $29 \%$ and $17 \%$ reported using chicken dung in rice or fish farms, respectively. On average, these practices are relatively new experiences to most farmers, with only about $23 \%$ reported practicing for 15 years or more. The average year of experience with the IAAS technology is 9 years. In a few (i.e. about 5.3\%) of the chicken-fish farms, the ponds are observed to be rectangular in shape with an average of $1.5 \mathrm{~m}$ water depth, and the chicken house is directly built above the pond floor at about $1.5 \mathrm{~m}$ above the water level. Most of the fish-rice-poultry farmers report access to secure land as an important constraint. Sources for land for either agriculture or aquaculture include inheritance $(35 \%)$, purchase $(15 \%)$, rent or lease $(26 \%)$, communal land $(12 \%)$ and others such as shared cropping or shared-fishing facility as in farms owned by EIGs and CIGs. For those who owned their personal farm only $11 \%$ reported having secured land titles in the form of a land certificate. Lands have been held as leases on average of 8 years. The complexity and intensity of the spatial integration of fish pond in agriculture activities increases where pressure of land is greatest such as in the peri-urban communes of Muyuka, Kumba and Bafut.

\subsection{Comparative Production Levels, Profitability and Risks in Integrating Aquaculture Systems}

Figure 4 highlights the production levels of poultry birds, and notes that monoculture leads to intensive production of the single enterprise. Farmers who engaged in the production of poultry birds alone seem to have higher potential to rear a larger stock of about 7300 birds per year. In situations of diversification of enterprises, farmers are observed to scale back their poultry operation and tend to rear fewer birds. While just about $16 \%$ of sampled farmers reared poultry birds under intensive production systems, their average stocking density was higher than those of integrated farmers who averaged about 1000 birds per year. Fish cum poultry farmers report on average 1375 birds while rice cum poultry farmers rear 2659 birds per year. When the three enterprises are combined farmers reduce their production levels to about 954 birds per year. This scaling down of poultry operations in integrated systems could be due to the increasing operation costs associated with diversification. 


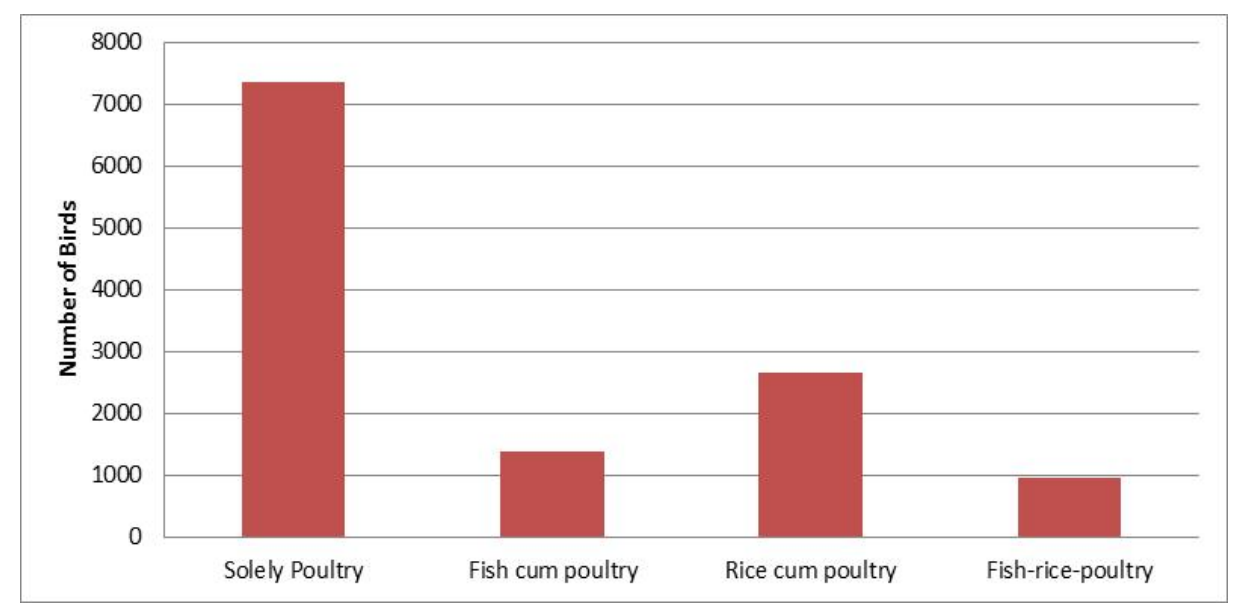

Figure 4. Poultry production levels (per farmer per year)

In the study zones, rice is mainly cultivated by farmers in the Ndop and Mbaw plains of the Northwest region. Typical communities in which rice is grown include Babungo, Bamunka and Bafut (mile 29). About 80\% of sampled farmers in the Northwest region cultivated rice. In the Southwest, just $9 \%$ of the farmers attempted to grow rice, largely in swamps in the Manyu division. Rice in the northwest is cultivated on diverse land quality, such as dry farmland, river-beds, valleys, lakes and swamp land. Rice is grown as a typical cash crop with more that $75 \%$ destined for the market. These were largely sold in market-centres and about $25 \%$ are allocated for home-use. The rice farms are divided into plots. Farmers had on average 2.5 rice plots, with each plot averaging 920 sq. meters and rice yields average $1500 \mathrm{~kg}$ per ha. Figure 5 reveals higher productive levels for rice monocultures, as yields are higher in rice monoculture farms. The philosophy associated with integrated systems, however, is violated in these monoculture farms that typically tend to apply fertilisers and other farm chemicals. IAAS farmers who grow rice rely largely on organic practice not only as a cost-cutting measure but also for the diversity of commodities that address household food security and safeguards in income. Based on the yield levels, the complementarity of rice enterprise is shown to be stronger in the rice cum poultry system than in the fish cum rice or in the complete integration of fish, rice and poultry.

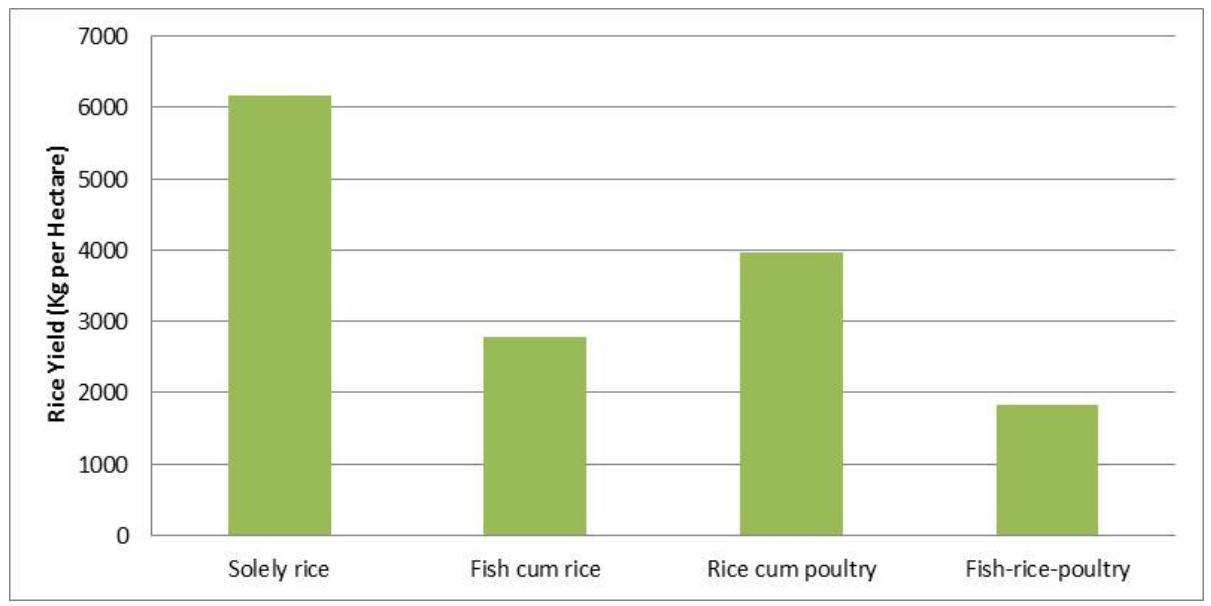

Figure 5. Rice production levels (kg per hectare per year)

However, the difference in fish production levels in the three integrated system is statistically insignificant. As shown in Figure 6, whether in the fish cum rice, fish cum poultry or fish cum rice cum poultry the average production levels are $1595 \mathrm{~kg}^{-1} \mathrm{yr}^{-1}, 1350 \mathrm{~kg}^{-1} \mathrm{yr}^{-1}$ and $1435 \mathrm{~kg}^{-1} \mathrm{yr}^{-1}$, respectively. This is an opportunity to exploit fish systems no matter the enterprises that farmers wish to anchor with fish production. Under the rice-fish-poultry system, about 55\% of fish farmers think their harvest in the last three years was good. All the sampled farmers acknowledge that culturing fish to supplement seasonal or year-round scarcity is attractive to 
supplement household food security, enhance social assets or even to provide seasonal cash income. Two strategies are commonly used to increase rice-fish production: stocking a higher percentage of rice-fields or maintaining/enhancing natural biodiversity. According to the farmers, the primary economic benefit IAAS is principally from producing marketable products. They affirm that the effective marketing of fish in particular is an important factor in the long-term economic sustainability of their enterprises. However, this demands technical, innovative and cooperative production and marketing strategies. They therefore require support from governmental and non-governmental agencies. Successful farmers are already catering for the market demand for certain species of fish, while for some, constraints to market access impact on their economic viability. About $19 \%$ report selling their fish harvests at the pond-site, while $63 \%$ take to the open market using head-portage, taxi and wheelbarrow (or push-cart), taking on average 32 minutes to reach market centres.

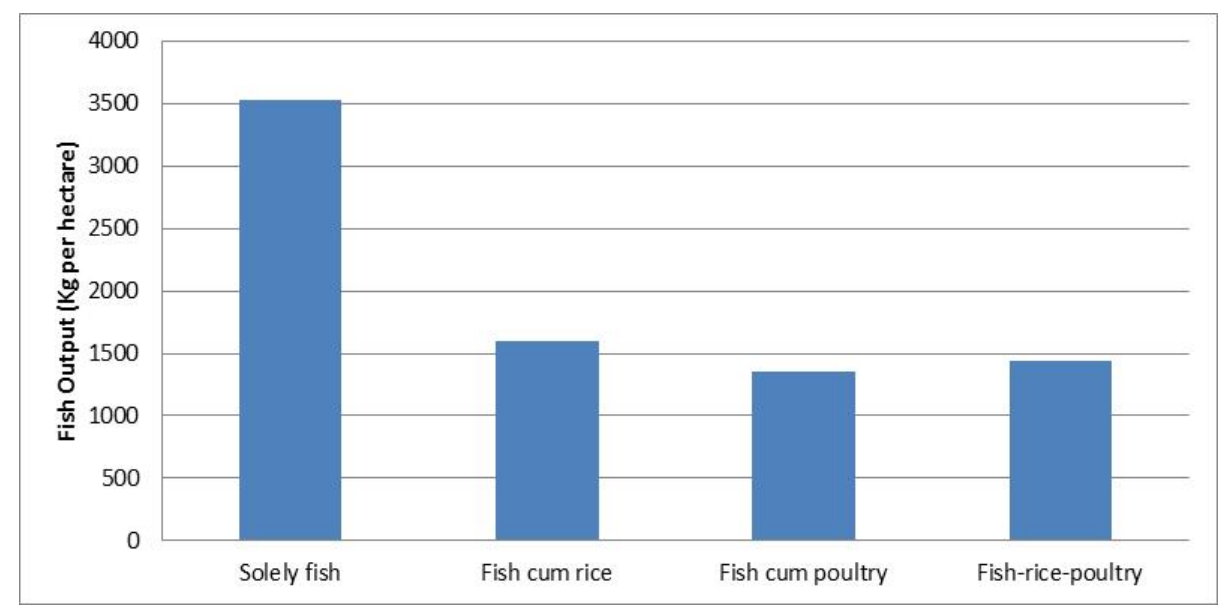

Figure 6. Fish production levels (kg per hectare per year)

Aquaculture is revealed to be profitable in Figure 7. The annual revenues realised exceed the costs incurred, no matter the system. In monocultures of solely fish or rice or poultry farmers realize a net profit of 385,550 FCFA (US\$ 771), 275,990 FCFA (US\$ 552) and 625,210 FCFA (US\$ 1,250), respectively. Poultry appears to be the most profitable enterprise. When integration is undertaken for two systems either as fish cum rice, fish cum poultry or rice cum poultry farmers realize net returns of 428,630 FCFA (US\$ 857), 785,650 FCFA (US\$ 1,571) and 865,990 FCFA (US\$ 1,732), respectively. The highest profits of 965,270 FCFA (US\$ 1,931) are obtained in the complete fish-rice-poultry system. The systems are overall profitable with about $53 \%$ of farmers reporting their net income to be in the range of 200,000 - 500,000 FCFA (US\$ 400 - 1000) per year. This is instructive on the benefits which may accrue to farmers scaling-down activities, cost cutting measures and exploiting the ecological complementarity of agricultural enterprises. Fish farming is largely a commercial enterprise for more than $90 \%$ of the farmers with over $75 \%$ of their harvests allocated for markets. The market income improves on household welfare. Some of the households report that additional income is spent on improving household living conditions, such as the purchase of equipment (e.g. TV, radio, bicycle), acquiring of fishing and farming equipment, investments on health and housing, as well as for social expenses (marriage, death celebrations). 


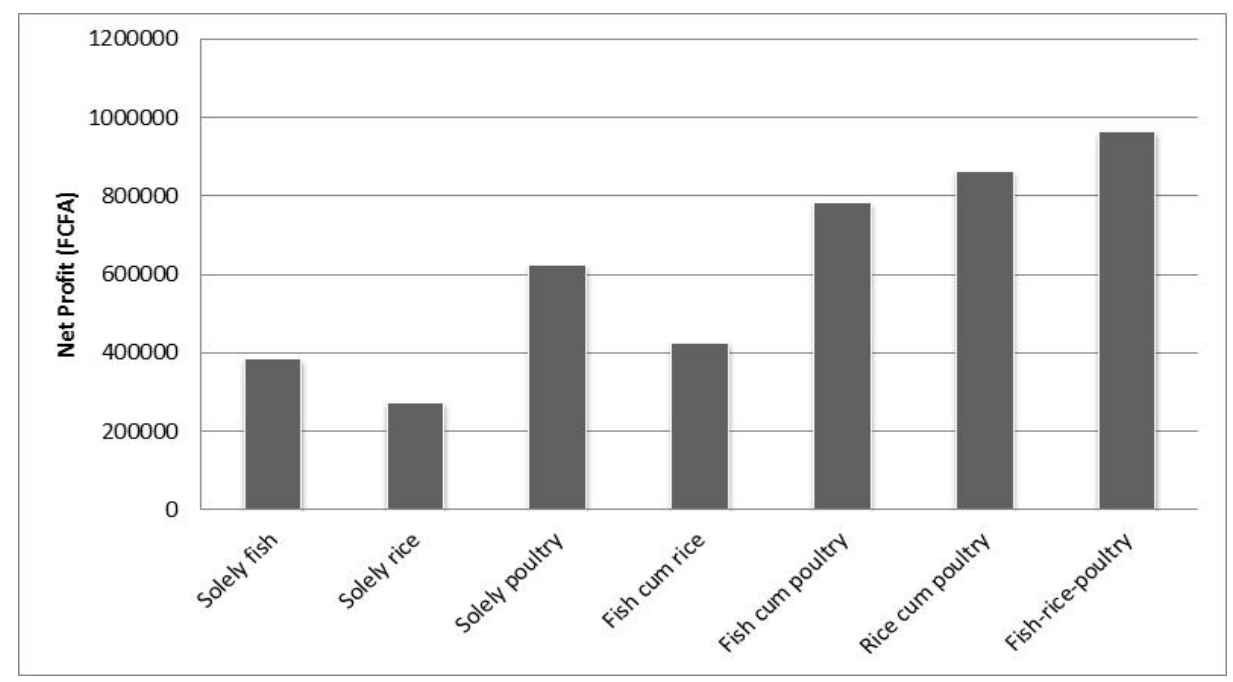

Figure 7. Comparative profitability of different enterprises and systems (per farmer)

The profitability of the integrated farms may be influenced by a range of risk factors, including technical, biological, environmental, financial, marketing, administrative and bureaucratic (legislative/regulatory) processes. As shown in Table 3, for significant proportion of farmers the final decision to either commence or continue IAAS is broadly dictated by availability of water and land resources, levels of demand of intended market, price levels especially for live animals, training and extension support, cost of production and level of proposed capital investment and projected revenues or income. Access to financial resources is re-echoed as an important impediment to expand or start new enterprises. The major sources of credit for fish-rice-poultry farmers include commercial bank (6\%), microfinance (37\%), friends and relatives $(29 \%)$ and a plethora of other sources that include owned savings $(25 \%)$, borrowing from money lenders $(17 \%)$ and donations or assistance from local and international NGOs (11\%). From those who obtained credit in the last three years, about 957,000 FCFA (US\$ 1,914) was borrowed in the last three years, with $32 \%, 24 \%$ and $39 \%$ allocated to needs of the fishery, rice and poultry enterprises, respectively. For farmers that received resources or technical support from government institutions and NGOs, this included provision of fingerlings, planting materials, vaccination and production training. Just about 33\% of farmers report being satisfied with this type of support. About $29 \%$ of this support came from government institutions, $11 \%$ from private business organizations and $40 \%$ from non-governmental civil society organizations.

Table 3. Challenges in aquaculture

\begin{tabular}{ll}
\hline Reported constraint & Percentage (\%) \\
\hline Lack of adequate information & 55.00 \\
Lack of extension contacts & 76.00 \\
Unavailability of adequate land & 35.00 \\
Investment capital & 56.00 \\
Unavailability of high quality seedlings (fry) & 65.00 \\
Unavailability of high quality fingerlings & 85.00 \\
Poultry diseases & 36.00 \\
Soil & 12.00 \\
Water & 19.00 \\
Labour (manpower) & 22.00 \\
Marketing & 26.00 \\
\hline
\end{tabular}

Source: Survey (2013). 


\subsection{Statistical Determinants of Integrated Aquaculture Systems}

Some socioeconomic factors that may influence the gains in aquaculture system were tested for their statistical significance. The results are presented in Table 4. All the parameter estimates have the expected positive sign indicating a positive correlation and influence on farm revenue. The magnitude of the coefficients is similarly significant as indicated by the t-statistics. For example, a one-percent increase in plot size may significantly improve revenues by $3.1 \%$. As indicated by the coefficient of labour, when there is a one-percent change in labour, revenue improves by $0.8 \%$. The more experienced a farmer, revenue improves by $0.7 \%$. Similarly, land access and ownership which are proximate to tenure, may influence revenue by $0.6 \%$. Interestingly, improved credit accessibility changes revenue by $3.5 \%$. Education is an important variable as it has a positive relationship with integrated aquaculture revenue. Extension services equally play a major role in fish production activities. Contacts with extension service agents improves revenue stream by $0.3 \%$. More importantly, enterprise integration is shown to have a positive and direct relationship with farm revenue. This is also true for land tenure which is shown to significantly increase farm revenue.

However, for significant proportion of farmers the final decision to undertake IAAS is influenced by bioeconomic and sociocultural constraints (Tidwel et al., 2001; Worby, 2001). When asked, farmers linked the potential for IAAS to other options that included developing water supplies for fish production. The lakes, swamps, mangroves, valleys and other marshy lands required extensive physical investments which are beyond the financial capability of the farmers. While some of these water-bodies are common property, their structure and management can sometimes be developed to increase availability of fish at low cost. For private owned fish-ponds and tanks, it is observed that filling vacant ecological niches may improve on the productivity, e.g. introducing tilapia into man-made tanks in Malende, Yoke and Muyuka. Such fisheries can be intensified, and highly productive, through stocking hatchery-produced juveniles. However, this approach is reported to have failed following past efforts because of the costs and difficulties of management.

Table 4. Econometric results of factors influencing income from integrated fish systems

\begin{tabular}{|c|c|c|c|}
\hline Parameter & Coefficient & t-statistic & Others \\
\hline Constant & 8.93 & $4.65 * * *$ & \\
\hline ln Plot size & 0.31 & $3.98 * * *$ & \\
\hline $\ln$ Labour & 0.08 & $2.07 * *$ & \\
\hline ln Credit & 0.35 & $1.71 * *$ & \\
\hline $\ln$ Education & 0.09 & $1.54 *$ & \\
\hline $\ln$ Experience & 0.07 & $1.49 *$ & \\
\hline Gender & 0.02 & $1.83 * *$ & \\
\hline Access to Extension & 0.03 & $1.69 *$ & \\
\hline Enterprise Integration & 0.22 & $2.17 * *$ & \\
\hline Land tenure & 0.06 & $3.56 * * *$ & \\
\hline
\end{tabular}

R-sq: 0.63

F-stat: 27.15

DW: 1.39

Note. $* * *$ statistical significance at $1 \%, * *$ statistical significance at $5 \%,{ }^{*}$ statistical significance at $10 \%$ (using the two-tailed t-test).

These findings are instructive on the direction of effort to disseminate and promote adoption of IAAS. There are repeated inferences to external factors such as government policy impacting production. In the rice dominant Mbaw plains of the Northwest region, due to the economic constraints in the 1990s and early 2000 following Cameroon's macroeconomic Structural Adjustment Reforms with policies that impacted production and export of rice, both private and group-based communal production suffered through increased imports of rice and fish into the country. However, adopting pond-based integrated aquaculture was one of the remediation efforts to arrest disinvestments in the sector. 
In the two regions studied, the uptake of IAAS is as much linked to changes in the rural economy as to technical factors. Farmers in Bamunka, for instance, linked expansion of fish production to increased population pressure and its impacts, particularly through irrigation and more intensive rice production. In peri-urban locales such as Bafut and Muyuka, infrastructure development are particularly important with some farmers exploiting pits from soil used in road and house building for pond construction and in turn fish culture. Along the Atlantic west coast in the Southwest region, aquaculture supplements wild catch though never replacing it for most of the farmers. In terms of marketing and meeting consumer demand, farmed fish is also harvested outside the wet-rainy season. Typically, in the wet-rainy season stocks are plentiful given increased access to water resources, both in upland and riverine areas. The availability of farmed-fish in some communities in the dry season means that consumers and fish-traders begin to appreciate and take advantage of the availability and size consistency of cultured fish, even if such fish command higher prices.

Overall, indigenous species remain more popular than exotic cultured fish. Tilapias and local species are widely accepted and demand is growing significantly. This increase in demand puts pressure on farmers and traders, and the ensuing pressure brings with it positive and negative consequences. For instance, there is increased exploitation of marginal land to produce rice. In the Atlantic coastal communities, competition is growing between live cultured fish and wild catch from the open seas. In the Babungo municipality, for instance farmers continue to exploit indigenous rice field fish for daily household consumption and invest in cultured fish as a cash crop. In contrast, in Malende and Muyuka, imports of fresh sea fish some 60 kilometres from Limbe in the Atlantic coast, tend to discourage fish culture. However, while urban residents are more likely to consume sea fish, the rural communities rely on, and prefer the indigenous cultured fish because of their low price and ready availability.

\section{Conclusion}

This investigation notes that farmers integrate fish cum rice cum poultry. There are significant potentials for further development of the systems. The challenge for Cameroon and countries with similar levels of development is to ensure that the system evolves not only from subsistence levels to agro-industrial scale, but also widespread adoption by small-scale producers particularly in wetland communities. However, for widespread adoption of this kind of farming system and for maximum explotation of its potential there is a need for more information on the different types of systems and the training of farmers. Training should exploit the dissemination of information related to the volume of different animal manures that should be applied in fish pond, the proper stocking density, water quality, types of nutrients in the pond and their volumes, and feed conversion ratio. This information is necessary for effective pond management. More important, in setting up integrated farming systems consumer preference and the cosmopolitan nature of the demand should be taken into consideration, so that produce from rice-fish-poultry culture system may be more acceptable among the consumers. To promote adoption of IAAS, farmers will therefore require the support of key stakeholders including Ministry of Fishery, development agencies, municipal authorities and local government authorities. In addition, easing the land tenure constraint as well as improving farmers' education and training will require extension service support to ensure farmers have adequate levels of expertise and that best-practice management and production techniques are implemented.

\section{Acknowledgements}

This research is a component of the 'Sustainable Integrated pond based aquaculture with rice and poultry production: Economic, social and environmental assessment,' (SIARP-ESEA) Project number 03/PA/10 funded by the World Bank/MDTF through the CORAF/WECARD under its Livestock, Fisheries and Aquaculture Programme. The authors wish to thank the anonymous reviewers for their comments, Emmanuel K. Ajani of the University of Ibadan, Nigeria and Julius Olapade of Njala University, Sierra Leone for valuable insights.

\section{References}

Abiona, B. G., et al. (2012). Enterprise Mix in Integrated Fish Farming in Ogun State, Nigeria, Journal of Agricultural Science, 4(1), 171-180.

Ayoola, S. O. (2010). Sustainable fish Production in Africa. African Journal of Food Agriculture Nutrition and Development, 10(5).

Brummett, R. E., Youaleu, J. L. N., Tiani, A. M., \& Kenmegne. (2010). Women's traditional fishery and alternative aquatic resource livelihood strategies in the Southern Cameroonian Rainforest. Fisheries Management and Ecology, 17(3), 221-230. http://dx.doi.org/10.1111/j.1365-2400.2009.00702.x

Edwards, P. (1998). A systems approach for the promotion of integrated aquaculture. Aquaculture Economics \& 
Management, 2(1), 1-12. http://dx.doi.org/10.1080/13657309809380209

Edwards, P., \& Little, D. (2003). Integrated Livestock-fish farming system. Food and Agriculture Organization of the United Nations, Rome.

Edwards, P., Little, D. C., \& Yakupitiyage, A. (1996). A comparison of traditional and modified inland artisanal $\begin{array}{lllll}\text { aquaculture } & \text { Aquaculture } & \text { Research, } & \text { 777-788. }\end{array}$ http://dx.doi.org/10.1111/j.1365-2109.1997.tb01002.x

Edwards, P., Pullin, R. S. V., \& Gartner, J. A. (1988). Research and education for the Development of integrated crop-livestock-fish farming systems in the tropics. ICLARM Studies and Reviews (Vol. 16, p. 53). ICLARM, Manila.

Eyo, A. A., Ayanda, J. O., \& Adelowo, E. O. (2006). Essentials of Integrated Fish Farming (pp. 12-20). National Institute for Freshwater Fisheries Research, New Bussa.

Fakoya, E. O., \& Daramola, B. G. (2005). Socio Economic Factors Influencing Farmers Participation in Integrated Fish Farming. Rural Sociology Journal, 2.

FAO. (1999). Review of the state of world fishery resources: Inland fisheries. FAO Fisheries Circular No. 942 (p. 53). Rome.

FAO. (2000). Small ponds make a big difference: Integrating fish with crop and livestock farming. Farm Management and Production Economics Service inland Water Resources and Aquaculture Service. FAO, Rome.

FAO. (2004). Aquaculture Extension in sub-Saharan Africa. Fisheries Circular No. 1002. Food and Agriculture Organization of the United Nations, Rome.

FAO. (2014). State of World Fisheries and Aquaculture (SOFIA). Department of Fisheries and Aquaculture, Food and Agriculture Organization of the United Nations, Rome.

Folke, C., \& Kautsky, N. (1992). Aquaculture with its environment: Prospects for sustainability. Ocean Coast. Manag., 17, 5-24. http://dx.doi.org/10.1016/0964-5691(92)90059-T

Gabriel, U., Akinrotimi, O. A., Bekibele, D. O., Anyanwu, P. E., \& Onunkwo, D. N. (2007). Economic Benefit and Ecological Efficiency of Integrate Fish Farming in Nigeria. Science Research and Essay, 2(8), 302-308.

Kipkemboi, J., van Dam, A. A., \& Denny, P. (2006). Biophysical Suitability of Smallholder Integrated Aquaculture-Agriculture Systems (Fingerponds) in East Africa's Lake Victoria Freshwater Wetlands. International Journal of Ecology and Environmental Sciences, 32(1), 75-83.

Krom, M. D., Neori, A., van Rijn, J., Poulton, S. W., \& Davis, I. M. (2001). Working towards environmentally friendly marine farming. Ocean Chall., 10, 22-27.

Lewis, D. (1997). Rethinking aquaculture for resource-poor farmers: Perspectives from Bangladesh. Food Policy, 22, 533-546. http://dx.doi.org/10.1016/S0306-9192(98)00006-2

Ofori, J., Abban, E. K., Otoo, E., \& Wakatsuki, T. (2005). Rice-fish culture: An option for smallholder Sawah rice farmers of the West African lowlands. Ecological Engineering, 24(3), 233-239. http://dx.doi.org/10.1016/j.ecoleng.2004.12.017

Pouomogne, V., \& Brummett, R. (2002). Fish culture in Cameroon: Small-scale commercial systems for rural poor. Global Aquaculture Advocate, 5(6), 86-87.

Tidwell, J. H., \& Allen, G. L. (2001). Fish as food: Aquaculture's contribution. Ecological and economic impacts and contributions of fish farming and capture fisheries. EMBO Rep., 21, 958-963. http://dx.doi.org/10.1093/embo-reports/kve236

Vincke, N. M. J. (1992). Integrated Farming of Fish and Livestock: Present Status and Future Development. Food and Agriculture Organization of the United Nations, Rome.

Wetengere, K. (2009). Socioeconomic factors critical for adoption of fish farming technology: The case of selected villages in eastern Tanzania. International Journal of Fisheries and Aquaculture, 1(3), 28-37.

Williams, M. J. (1997). Aquaculture and Sustainable Food Security in the Developing World. In J. E. Bardach (Ed.), Sustainable Aquaculture. John Wiley \& Sons, Inc., New York.

Worby, E. (2001). Socio-cultural considerations when introducing a new integrated agriculture-aquaculture technology. FAO Fisheries technical paper (pp. 3-8). FAO, Rome. 


\section{Notes}

Note 1 . The exchange rate used is 1 USD $=500$ FCFA. Retrieved from http://www.xe.com

\section{Copyrights}

Copyright for this article is retained by the author(s), with first publication rights granted to the journal.

This is an open-access article distributed under the terms and conditions of the Creative Commons Attribution license (http://creativecommons.org/licenses/by/3.0/). 